\title{
AKTOR DI BALIK SELEMBAR BATIK (STUDI KASUS DI LEMBUR BATIK CIMAHI)
}

\author{
ACTOR BEHIND A PIECE OF BATIK \\ A CASE STUDY IN BATIK VILLAGE, CIMAHI
}

\author{
Ria Intani T. \\ Balai Pelestarian Nilai Budaya Jawa Barat \\ Jl. Cinambo No. 136 Ujungberung-Bandung. \\ e-mail: ria_intani@yahoo.com
}

Naskah Diterima: 4 Januari 2017 Naskah Direvisi: 10 Februari 2017 Naskah Disetujui: 20 Februari 2017

\begin{abstract}
Abstrak
Batik adalah selembar kain yang dibuat secara ditulis, dicap, atau penggabungan antara keduanya. Dulu, ketika batik hanya diproduksi untuk lingkungan keraton, pembuatnya masih terbatas. Manakala batik keluar dari lingkungan keraton, pembuat batik meluas. Itu dulu, zaman di mana orang masih memiliki banyak waktu luang dan jenis pekerjaan belum beragam. Saat ini apabila di antara sejumlah orang masih ada yang mendedikasikan dirinya untuk menggeluti batik sebagai pengrajinnya, tentu ada alasan yang melatarinya. Penelitian ini bertujuan untuk mengetahui cara perekrutan pengrajin, pengetahuan membatik, kondisi pengrajin, serta konsep kerja pengrajin. Penelitian ini menggunakan metode kualitatif dengan hasil penelitiannya dituangkan secara deskriptif. Hasil penelitian menunjukkan bahwa dedikasi menjadi pengrajin batik dilatari oleh rasa tanggung jawab dan kecintaan yang mendalam dengan dunia perbatikan. Dapatlah disimpulkan bahwa tanpa adanya keterlibatan hati, sulit bagi seseorang untuk dapat bertahan menjadi pengrajin. Mengingat, banyak jenis pekerjaan lain yang besaran penghasilannya lebih menjanjikan.
\end{abstract}

Kata kunci: aktor, selembar batik..

\begin{abstract}
Batik is a cloth made in written, printed, or a combination between the two. In the past, when batik was only produced for the palace, the makers were still limited. Another case with when batik came out of the palace, batik makers were expanding. That was then, an era where people still had a lot of spare time and the type of work had not been varied. Today, if among a number of people consist of people who dedicate themselves as batik craftsmen, absolutely there is a reason behind of it. This study aims were to determine how the recruitment, knowledge, the condition, and working concept of batik craftsmen. This study uses qualitative research and the findings are outlined descriptively. The results shows that the dedication of batik craftsmen is backed by a sense of responsibility and a deep love with the world of batik. It can be concluded that without the involvement of their love, it is difficult for a person to be able to survive into a batik craftsman. Bearing in mind,there are many other types of work that have more promising incomethe amount of income is more promising.
\end{abstract}

Keywords: Actor, Piece of Batik..

\section{A. PENDAHULUAN}

Istilah batik dapat dipastikan tidak awam bagi sebagian besar masyarakat. Namun apa sesungguhnya batik itu, pahamkah mereka yang menyebut-nyebut suatu benda dengan istilah batik itu? Apakah semua lembaran kain yang bermotifkan batik dapat disebut dengan batik? Bagi mereka yang paham akan arti batik, mereka hanya akan menyebut suatu benda dengan istilah batik apabila benda tersebut merupakan lembaran kain yang dibuat dengan cara ditulis, dicap, atau ditulis sekaligus dicap. Bahannya adalah 
malam (lilin), sedangkan medianya berupa canting dan cap.

Arti batik seperti tersebut di atas bersumber dari dua versi. Versi pertama menyebutkan bahwa istilah batik diambil dari istilah mbatik, sedangkan versi kedua menyebutkan bahwa istilah batik berasal dari kata "tik". Sarmini memaparkan (2009: 674), bahwa mbatik secara etimologi dikenal berasal dari frase Jawa: "amba titik", yang berarti "menggambar titik". Akhiran "tik" dapat berarti "titik kecil" dan proses mbatik dapat diartikan sebagai proses penggambaran dengan canting secara repetitif sedemikian sehingga membentuk garis hingga akhirnya memberi pola tertentu sebagaimana dapat kita apresiasi secara utuh. Adapun kata "tik", dijelaskan oleh Sarmini (2009: 675) berarti titik. Batik ada hubungannya dengan titik dikarenakan dalam proses pembuatan batik melalui tahapan penetesan malam (lilin) ke kain putih yang akan dijadikan batik nantinya. Saat proses penetesan tersebut, tetesan malam (lilin) itu akan berbunyi "tik-tiktik" sehingga akhirnya lahirlah kata "batik".

Serupa dengan apa yang terurai di atas, Hamzuri (1994: VI) mengatakan bahwa yang dimaksud dengan batik ialah lukisan atau gambar pada mori yang dibuat dengan alat bernama canting. Membatik menghasilkan batikan berupa macammacam motif dan mempunyai sifat-sifat khusus yang dimiliki oleh batik itu sendiri. Dalam perkembangannya dipergunakan alat lain untuk mempercepat proses pengerjaan, yakni dengan cap. Untuk membedakan masing-masing disebut "batik tulis" dan "batik cap".

Chusnul Hayati (2012: 25) dalam tulisannya tentang batik Pekalongan menuliskan bahwa adanya pengertian tentang batik yang bermacam-macam maka selanjutnya Dewan Standarisasi Tekstil Indonesia (DSTI) yaitu yayasan yang menangani standar tekstil dan batik memberikan definisi tentang batik. Batik adalah kain tekstil hasil pewarnaan pencelupan rintang menurut corak khas ciri batik Indonesia dengan menggunakan lilin batik sebagai zat perintang. Definisi tersebut selanjutnya dijadikan definisi oleh Standar Industri Indonesia (SII) dan dikeluarkan secara resmi oleh Departemen Perindustrian.

Tanggal 12 Maret 1996, pada Seminar Nasional tentang batik di Jakarta, dilakukan standar nasional mengenai pengertian batik. Batik diartikan sebagai kain yang menggunakan proses perintang malam atau lilin sebagai bahan media untuk menutup permukaan kain dalam proses pencelupan warna (Hayati, 2012: 26). Dapat disimpulkan bahwa inti dari pengertian batik terletak pada penggunaan malam/lilin.

Batik sebagai benda fungsional mewujud dalam bentuk sandang dan dekorasi rumah. Oleh karena fungsinya tersebut, batik menjadi tampak ada di mana-mana. Apalagi untuk saat ini, saat di mana batik sudah mendapat pengakuan dari United Nations Educational Scientific and Cultural Organization (UNESCO) pada 2 Oktober 2009 sebagai warisan budaya dunia takbenda.

Penetapan UNESCO atas batik sebagai warisan budaya takbenda milik Indonesia membawa konsekuensi bagi segenap bangsa Indonesia untuk turut serta melestarikan batik. Pelestarian batik tidak hanya menjadi tanggung jawab pemerintah, melainkan segenap bangsa Indonesia. Konsep pelestarian di dalam Peraturan Bersama Menteri Dalam Negeri dan Menteri Kebudayaan dan Pariwisata Nomor 40 dan 42 Tahun 2009 adalah:

"Pelestarian adalah upaya perlindungan, pengembangan, dan pemanfaatan kebudayaan yang dinamis. Perlindungan adalah upaya pencegahan dan penanggulangan yang dapat menimbulkan kerusakan, kerugian, atau kepunahan kebudayaan berupa gagasan, perilaku, dan karya budaya, termasuk harkat dan martabat serta hak budaya yang diakibatkan oleh 
perbuatan manusia ataupun proses alam. Pengembangan adalah upaya dalam berkarya yang memungkinkan terjadinya penyempurnaan gagasan, perilaku, dan karya budaya berupa perubahan, penambahan, atau penggantian sesuai tata dan norma yang berlaku pada komunitas pemiliknya tanpa mengorbankan keasliannya. Pemanfaatan adalah upaya penggunaan karya budaya untuk kepentingan pendidikan, agama, sosial, ekonomi, ilmu pengetahuan, teknologi dan kebudayaan itu sendiri" (Purwaningsih, 2015: 466).

Mengacu pada konsep pelestarian di atas menunjukkan bahwa bangsa Indonesia harus menjaga keberlangsungan batik dengan cara: menciptakan generasi baru pengrajin batik; batik tersebut dapat diterima oleh sebagian besar masyarakat Indonesia; dan batik tersebut digunakan oleh sebagian besar masyarakatnya. Apabila salah satu dari ketiga ketentuan tersebut tidak dapat dipenuhi maka ada kemungkinan hilanglah pengakuan yang sudah diberikan itu.

Dampak positif dari penetapan tersebut, di setiap kesempatan, di setiap kita melangkah, mata terantuk pada benda yang oleh orang disebutnya begitu saja sebagai batik. Batik yang dimaksud ada di mall-mall, pasar-pasar tradisional, di "toko-toko" yang berdiri di lingkungan perumahan, di "pasar kaget", di "warung berjalan" alias mobil, di penjaja keliling, dan lain-lain. Namun demikian apabila merujuk pada pengertian batik yang menjadi standar pemerintah, apakah semua yang terlihat mata itu adalah batik dalam arti yang sebenarnya? Tidak.

Manakala permintaan batik sudah sangat besar, pabrikan membaca peluang dengan mencetak "batik" secara mesin (printing) namun dengan tetap mempertahankan motif-motif yang biasa digunakan dalam batik. Produk pabrikan tersebut tidak dapat disebut dengan batik, melainkan kain bermotif batik. Seperti yang dikatakan Hamzuri (1994: 3), sesuai dengan perkembangan teknik modern maka cara mengerjakan batik dimodernisasi. Teknik modern ini menghasilkan kain dengan motif seperti batik, disebut kain motif batik. Tidak disebut dengan batik. Oleh karena jika peralatan dan cara pengerjaan dimodernisasi, predikat batik dan membatik akan hilang.

"Batik" alias kain bermotif batik seperti itulah yang sekarang tampak lebih mendominasi di pasaran. Rupanya pun, pasar sangat menikmati. Entah karena orang benar-benar tidak paham akan arti batik, orang tidak peduli apakah itu batik dalam arti yang sebenarnya atau bukan, atau karena harganya sangat terjangkau, dan lain-lain.

Bagi mereka yang ingin mengenal batik, untuk tidak terkecoh menilai antara batik dan bukan batik, di antaranya dicirikan dengan: lembaran kain bukan batik besaran harganya sangat miring, motif tercetak sangat rapi, apabila dilakukan pengulangan produksi antara satu kain dengan kain yang lain akan sama persis, dan teknik pembelian diukur secara meteran, bukan lembaran.

Saat ini, batik yang semula hanya dikonsumsi di lingkungan keraton, sudah menjadi pakaian rakyat kebanyakan, baik itu untuk batik tulis ataupun batik cap. Hanya saja untuk batik tulis, di mana besaran harganya jauh lebih tinggi dibandingkan besaran harga batik cap, masih menjadi pilihan orang-orang berduit. Dilihat dari sisi peruntukan, fungsi batik pada zaman dahulu masih terbatas sebagai kain, selendang, dan sarung. Dalam perkembangannya, manakala batik keluar dari lingkungan keraton, selain menjadi pakaian sehari-hari ibu-ibu (pakaian tidur), batik hanya difungsikan sebagai pakaian untuk acara-acara resmi. Adapun saat ini boleh dikatakan fungsi batik tidak berbatas ruang dan waktu. Artinya, sekarang ini batik dapat dikenakan di mana saja dan kapan saja. Kalau dulu batik hanya ada di acara hajatan, seminar, peresmian acara, 
dan lain-lain, saat ini batik ada di kantorkantor dan sekolah sebagai pakaian seragam, batik ada di rumah-rumah sebagai pakaian sehari-hari, batik ada di acara arisan, batik ada di acara reunian, batik ada di acara perpisahan, batik ada di acara keluarga, batik ada di acara jalanjalan, batik ada di pasar-pasar, batik ada di acara melayat, batik ada di rumah sakit, dan batik ada di berbagai acara dan tempat lainnya.

\begin{tabular}{ccc}
\multicolumn{2}{r}{ Pengenaan batik yang meluas } \\
tersebut juga \\
didukung
\end{tabular} diciptakannya model busana batik yang sangat beragam. Mulai dari model jadul alias zaman dulu hingga kekinian yang cenderung berkiblat ke busana "Barat", dari model untuk acara resmi hingga acara santai. Bahkan seringkali, dari modelmodel yang sudah tercipta, peruntukannya tidak lagi dibatasi. Artinya, mana busana resmi dan bukan resmi sifatnya samarsamar.

Akibat dari meluasnya penggunaan batik, nyaris di tiap-tiap kota/kabupaten di Provinsi Jawa Barat kemudian lahir ataupun lahir kembali sejumlah sanggar batik. Kalau dulu di Provinsi Jawa Barat hanya dikenal batik dari Cirebon (batik cirebonan, dengan Trusmi sebagai ikonnya), Indramayu (batik dermayon alias Indramayu), Ciamis (batik ciamisan), Garut (batik garutan), dan Tasik (batik tasikan), kini ada batik dari Sumedang (batik kasumedangan), Sukabumi, Bogor, Cianjur (batik cianjuran), Karawang, Purwakarta, Majalengka, Kota/Kabupaten Bandung, dan Kota Cimahi (batik Cimahi). Masingmasing daerah tersebut menciptakan motif dengan mengambil ikon atau potensi yang ada di daerahnya sebagai upaya menunjukkan identitas daerah yang bersangkutan.

Eksistensi sanggar-sanggar batik yang ada saat ini, sudah tentu tidak lepas dari faktor keberadaan pengrajin. Pengrajin merupakan aktor di balik terciptanya selembar batik. Pengrajin merupakan titik sentral di dalam keberlangsungan sanggarsanggar batik.

Bagi wilayah-wilayah yang dikenal sebagai daerah perbatikan, hal ihwal tentang pengrajin tidak menjadi persoalan besar. Sebabnya, di daerah perbatikan pada umumnya sanggar batik merupakan usaha yang sifatnya turuntemurun. Pengelolaan dan pewarisan ilmu diwariskan dengan pola satu turunan. Maksud dari pola satu turunan, seperti yang dipaparkan oleh Kasi Pengembangan Balai Pengelolaan Taman Budaya Provinsi Jawa Barat dalam rangka revitalisasi kesenian yakni, pewarisan dilakukan oleh orang tua kepada anggota keluarga yakni, kepada anak-anaknya atau kepada cucunya atau kepada cicitnya dan seterusnya. Apabila tidak ada keluarga, mencari tetangga, apabila tetangga juga tidak ada, mencari siapa saja yang berminat (Intani, 2016: 22).

Selanjutnya penelitian dibatasi lingkup wilayahnya yakni, di Lembur Batik Cimahi, sebuah sanggar batik yang terdapat di Kota Cimahi. Adapun ruang lingkup materinya meliputi: bagaimana cara sanggar batik merekrut pengrajin, pengetahuan membatik, kondisi pengrajin, dan konsep kerja. Selain juga gambaran tentang batik Cimahi, sanggar batik, dan ragam bahan dan alat yang digunakan, sebagai data pendukung.

Terkait dengan permasalahan penelitian maka perlu dikemukakan konsep tentang pengrajin dan konsep tentang kerja. Istilah pengrajin di dalam Kamus Besar Bahasa Indonesia (1988: 667) diartikan sebagai orang yang pekerjaannya (profesinya) membuat barang kerajinan. Adapun istilah "kerja" secara umum, dalam istilah baku, diartikan sebagai kegiatan melakukan sesuatu; sesuatu yang dilakukan untuk mencari nafkah; mata pencaharian (Tim Redaksi KBBI, 2013: 681). Adapun Sandra Wallman (1979: 1) mengemukakan bahwa:

"dalam setiap masyarakat "kerja" mempunyai sejumlah arti yang berbeda. Kerja dapat dianalisa ke 
dalam istilah transformasi fisik, transformasi sosial, aktivitas ekonomi atau identitas pribadi. Untuk pekerjanya sendiri kerja adalah suatu kebutuhan batiniah dan suatu usaha dan alinasi. Suatu gambaran tentang kerja tidak hanya mengingat akan apa yang dikerjakan, bagaimana itu dikerjakan dan siapa yang mengerjakannya, tetapi juga bagaimana dan oleh siapa kerja itu dievaluasi.

Dimensi (unsur pokok) di dalam kerja, menurut Wallman (1979: 4-22) meliputi:

- enerji (kekuatan yang digunakan untuk bekerja),

- insentif (perangsang untuk seseorang mau bekerja),

- $\quad$ sumber (asal-muasal pengetahuan/ilmu dan keterampilan),

- value (penilaian tentang rekan kerja),

- waktu (pemanfaatan waktu),

- tempat (pemanfaatan tempat),

- orang (dorongan menjadi pekerja dan kriteria dalam memilih pekerja),

- teknologi (peralatan serta cara yang digunakan), dan

- $\quad$ sistem (pola keseluruhan dari langkahlangkah kerja).

Sembilan unsur pokok kerja di atas, tidak dibaca secara ranking, melainkan satu dan lainnya sebagai satu kesatuan. Persepsi tentang kerja, dijelaskan oleh C. Kluckhohn (Kartawinata, 1994: 1), termasuk salah satu dari soal-soal yang paling tinggi nilainya dalam hidup manusia dan secara universal ada dalam tiap kebudayaan di dunia. Dijelaskan bahwa sedikitnya ada lima hal yang paling tinggi nilainya dalam hidup manusia, salah satunya adalah soal makna hidup dari pekerjaan, karya dan amal perbuatan manusia. Terkait dengan hal tersebut Koentjaraningrat (Kartawinata, 1994: 2) berpendapat bahwa:

"ada banyak kebudayaan yang menganggap bahwa manusia bekerja untuk mencari makan. Di lain pihak, banyak kebudayaan lain memberi makna yang lebih luas tentang bekerja, yakni manusia aktif bekerja untuk beramal memperindah lingkungannya, menolong orang lain yang kurang beruntung, atau untuk menghasilkan karya-karya agung. Banyak pula kebudayaan yang mengajarkan kepada warganya, bahwa manusia yang bekerja keras itu kelak mendapat karunia Tuhan. Dan, ada kebudayaan yang telah mengembangkan konsepsi bahwa kepuasan hidup terletak dalam kerja itu sendiri, serta kualitas dari hasil kerjanya. “

Menyambung pendapatnya di atas, Koentjaraningrat menyatakan bahwa kebudayaan itu terbagi atas kebudayaan agraris dan industri. Dan, dalam kebudayaan industri, makna karya adalah manusia bekerja keras untuk mendapat rahmat Tuhan atau kepuasan dari hasil kerja.

Adapun menurut Abdullah (1978: 3), kerja bisa merupakan usaha komersial, dianggap sebagai suatu keharusan demi hidup, atau sesuatu yang imperatif dari diri, ataukah sesuatu yang terikat pada identitas diri yang telah bersifat sakral.Identitas diri dalam hal ini adalah suatu yang telah diberikan oleh agama.

Terkait dengan masalah kerja, ada yang disebut dengan etos kerja. Kata "etos" menurut Franz von Magnis (Kartawinata, 1994: 1) menunjukkan arti sikap kehendak. Dalam arti yang lebih luas kata "etos" berarti sikap kehendak yang dituntut terhadap kegiatan tertentu. Atau dengan kata lain menurut Franz von Magnis (Kartawinata, 1994: 2) etos kerja adalah sikap yang dikehendaki seseorang terhadap kegiatan kerjanya atau bagaimana ia menentukan sikapnya sendiri terhadap pekerjaannya. Dengan demikian, dengan menyimak pengertian di atas, dapatlah dikatakan bahwa kualitas kerja seseorang bergantung dari etos kerjanya.

Penelitian tentang batik di Jawa Barat, Jawa Tengah, dan Madura telah 
banyak dilakukan. Di antaranya selain yang dilakukan oleh penulis secara mandiri maupun tim, juga oleh beberapa penulis lain. Seperti: penelitian tentang Batik Dermayon, memfokuskan pada ragam motif. Penelitian ini dilakukan secara tim oleh penulis dan kawan-kawan; Batik Trusmi, memfokuskan pada sistem teknologi. Penelitian ini dilakukan secara tim oleh Dady Permadi dan kawan-kawan; Batik Ciamisan, memfokuskan pada kajian nilai yang terkandung di dalam motifmotifnya. Penelitian ini dilakukan oleh Lina Herlinawati; Batik Kasumedangan, memfokuskan pada corak dan teknik pembuatan. Penelitian ini dilakukan oleh penulis; Batik Cimahi, memfokuskan pada sejarah batik. Penelitian ini dilakukan oleh Lasmiyati; Batik Banyumasan, memfokuskan pada simbol, makna, dan nilai filosofis. Penelitian ini dilakukan oleh Ariani; Batik Pekalongan, memfokuskan pada perkembangan batik Pekalongan. Penelitian ini dilakukan oleh Hayati; dan Batik Madura, memfokuskan pada faktorfaktor yang memengaruhi perkembangan industri batik Madura. Penelitian ini dilakukan oleh Christriyati Ariani. Dengan demikian dengan melihat penelitian yang tersebut di atas, penelitian ini memiliki fokus bahasan yang berbeda.

\section{B. METODE PENELITIAN}

Metode yang digunakan dalam penelitian ini adalah metode kualitatif dengan hasil penelitiannya dituangkan secara deskriptif. Menurut Suyanto dan Sutinah, juga Tylor dan Bogdan, metode penelitian kualitatif adalah penelitian yang menghasilkan data deskriptif tentang katakata lisan ataupun tertulis dan tingkah laku yang diamati dari orang yang diteliti (Garna, 2009: 46).Teknik pengambilan datanya dengan wawancara, pengamatan, dan studi pustaka.

Proses penelitian diawali dengan studi pustaka. Studi ini selain dimaksudkan sebagai referensi, juga untuk melengkapi data yang tidak didapat melalui wawancara. Tahap selanjutnya adalah studi lapangan. Pada tahap ini dilakukan wawancara dan pengamatan. Materi wawancara yang diangkat sesuai dengan ruang lingkup materi penelitian.

\section{HASIL DAN BAHASAN \\ 1. Sekilas Daerah Penelitian}

Kota Cimahi secara administratif berada di Provinsi Jawa Barat. Kota ini terletak di antara $107^{\circ} 30^{\prime} 30^{\prime \prime}$ BT $107^{\circ} 34^{\prime} 30^{\prime \prime}$ dan 6 6050 $00^{\prime}$ - 6 $6^{\circ} 56^{\prime} 00^{\prime}$ " Lintang Selatan. Kota Cimahi berluas 40,2 Km2 dan menurut UU No. 9 Tahun 2001, kota ini memiliki batas-batas administratif sebagai berikut :

- Sebelah utara berbatasan dengan Kecamatan Parongpong, Kecamatan Cisarua, dan Kecamatan Ngamprah Kabupaten Bandung Barat.

- Sebelah barat berbatasan dengan Kecamatan Padalarang, Kecamatan Batujajar, dan Kecamatan Ngamprah Kabupaten Bandung Barat.

- Sebelah timur berbatasan dengan Kecamatan Sukasari, Kecamatan Sukajadi, Kecamatan, Cicendo dan Kecamatan Andir Kota Bandung.

- Sebelah selatan berbatasan dengan Kecamatan Marga Asih, Kecamatan Batujajar, Kabupaten Bandung Barat, dan Bandung Kulon Kota Bandung.

Kota Cimahi meliputi 3 kecamatan dan terdiri atas 15 kelurahan. Lebih rincinya sebagai berikut: Kecamatan Cimahi Utara terdiri atas 4 kelurahan, Kecamatan Cimahi Tengah terdiri atas 6 kelurahan, dan Kecamatan Cimahi Selatan terdiri atas 5 kelurahan. Berikut ini adalah daftar kecamatan dan kelurahan di Kota Cimahi:

- Kecamatan Cimahi Selatan: Kelurahan Cibeber, Kelurahan Cibeureum, Kelurahan Leuwigajah, Kelurahan Melong, dan Kelurahan Utama.

- Kecamatan Cimahi Tengah: Kelurahan Baros, Kelurahan Cigugur Tengah, Kelurahan Cimahi, Kelurahan Karangmekar, Kelurahan Padasuka, dan Kelurahan Setiamanah. 
- Kecamatan Cimahi Utara: Kelurahan Cipageran, Kelurahan Citeureup, Kelurahan Pasirkaliki, dan Kelurahan Cibabat, yang merupakan kelurahan di mana sanggar Lembur Batik Cimahi berdiri

(http://www.cimahikota.com/datawilayah-kota-cimahi.html).

\section{Batik Cimahi}

Lasmiyati (2012: 28) memaparkan bahwa batik Cimahi tercipta atas gagasan Dewan Kerajinan Nasional Daerah (Dekranasda) Kota Cimahi yang mengadakan kompetisi tentang corak batik.Kompetisi ini diadakan untuk menemukan corak batik Cimahi disesuaikan dengan potensi yang ada di Kota Cimahi. Dari hasil kompetisi tersebut dihasilkan lima motif batik, yaitu: kujang, ciawitali, cireundeu, curug 'air terjun' Cimahi, dan Pusdik (pusat pendidikan) militer.

Dipaparkan oleh Lasmiyati (2012: 31-37), motif kujang diciptakan oleh Mohamad Yaser. Motif kujang ada dua jenis, yakni: rereng kujang dan kujang cakra. Motif ciawitali atau motif bambu diciptakan oleh Didi Sahadi. Motif ini diciptakan untuk menggambarkan potensi bambu yang dimiliki Kota Cimahi, tepatnya di Kampung Ciawitali, Kecamatan Cimahi Tengah. Nama "ciawitali" diambil dari kata awi yang artinya bambu. Motif cireundeu, motif ini diciptakan oleh Dadang. Cireundeu adalah nama kampung yang berada di Leuwigajah Cimahi Selatan. Kampung ini memiliki kekhasan yakni, masyarakatnya mengkonsumsi sampeu 'singkong' sebagai pengganti nasi. Motif curug Cimahi, curug Cimahi merupakan salah satu objek wisata air terjun yang berlokasi di Cisarua. Motif Pusdik, diciptakan sebagai gambaran bahwa Kota Cimahi merupakan kawasan militer.

Setelah tercipta motif Cimahi, selanjutnya salah satu pengusaha di Kota Cimahi tertarik untuk mengggeluti dunia perbatikan. Ia lalu menghimpun generasi muda yang ada di sekitar tempat tinggalnya, khususnya yang belum memiliki pekerjaan alias masih menganggur, untuk menggeluti dunia yang sama. Mereka dihimpun dalam suatu wadah yang dinamai "Lembur Batik Cimahi”.

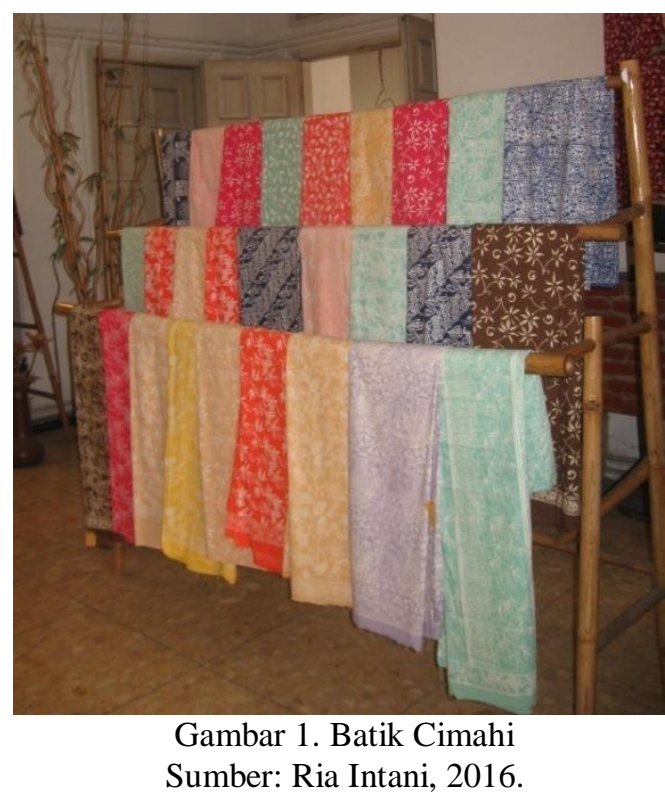

\section{Lembur Batik Cimahi}

Lembur Batik Cimahi merupakan sebuah sanggar yang membuat batik dengan motif khas Cimahi. Sanggar ini berdiri pada 2009 dengan bertempat di suatu komplek perumahan, di rumah tinggal sang pengusaha. Hanya tiga bulan di sana, selanjutnya sanggar batik berpindah tempat ke Jalan Pesantren Nomor 131, Kelurahan Cibabat, Kecamatan Cimahi Utara, Kota Cimahi.

Masih terbatasnya konsumen, Lembur Batik Cimahi memproduksi batik Cimahi lebih banyak didasarkan oleh pesanan. Oleh karena itu untuk "meramaikan" ruang pamer, batik nonCimahi pun turut digelar. 


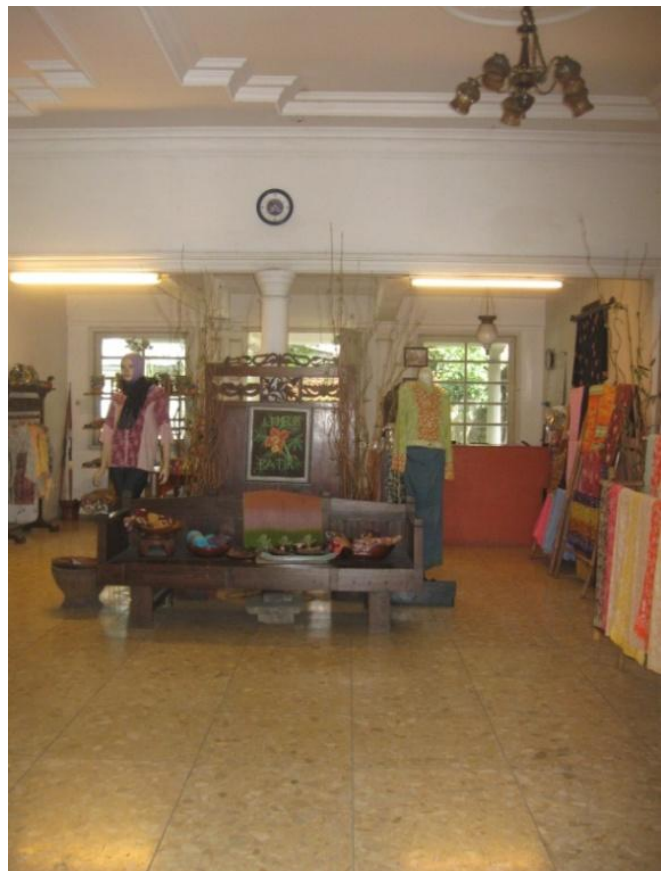

Gambar 2. Sanggar Lembur Batik Cimahi Sumber: Ria Intani, 2016.

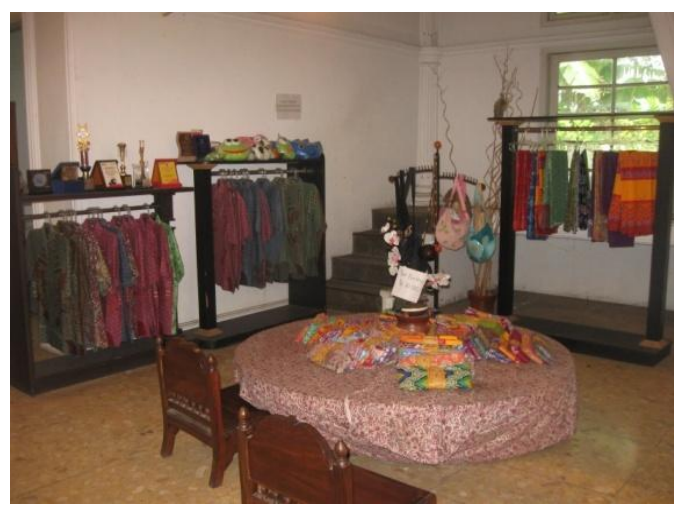

Gambar 3. Ruang Pamer Sumber: Ria Intani, 2016.

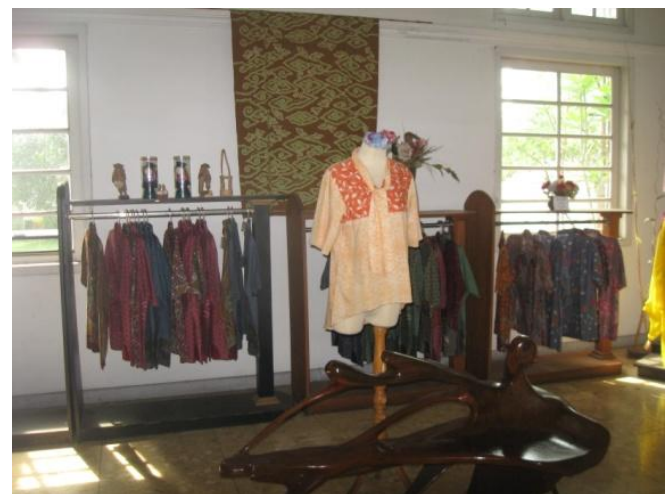

Gambar 4.Batik Motif Mega Mendung Turut "Meramaikan" Ruang Pamer Sumber: Ria Intani, 2016.
4. Ragam Bahan dan Alat Pembuatan Batik

Bahan utama yang digunakan untuk membatik adalah malam/lilin. Kain yang digunakan sebagai dasar membatik ada kain mori, sutera, dan semi sutera. Adapun peralatan yang digunakan merupakan peralatan umum dalam membatik, yang tidak mengalami perubahan dari dulu hingga sekarang. Peralatan tersebut di antaranya adalah:

- Canting, merupakan alat pokok untuk membatik, terbuat dari tembaga. Canting gunanya untuk menulis atau menorehkan malam atau lilin ke atas kain. Batik dari hasil menulis disebut dengan batik tulis.

- Cap, merupakan alat pokok kedua untuk membatik. Cap gunanya untuk mengecapkan motif ke atas kain, hasil batiknya disebut dengan batik cap. Sama halnya dengan canting, cap terbuat dari tembaga.

- Kompor, gunanya untuk memanaskan malam/lilin dalam katel. Kompor terbuat dari seng.

- Katel kecil, gunanya untuk wadah malam/lilin. Katel terbuat dari logam baja.

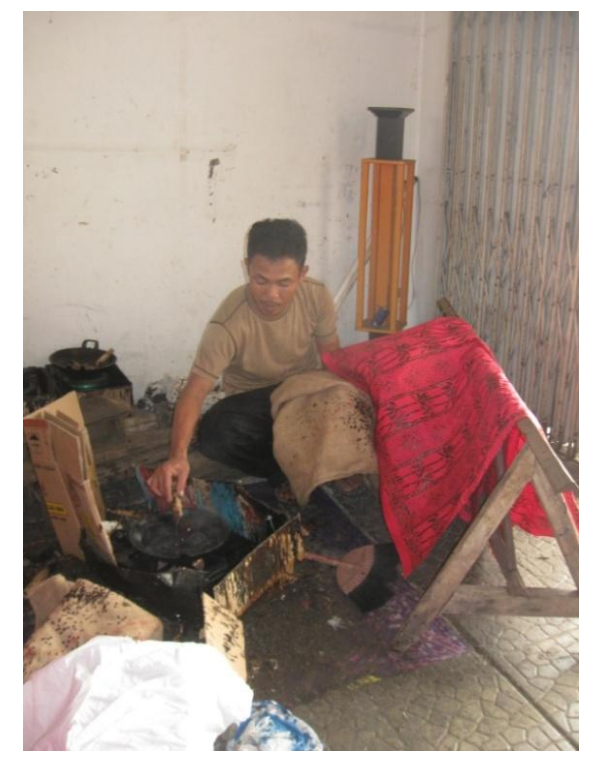

Gambar 5. Katel sebagai Wadah Malam Sumber: Ria Intani, 2016. 
- Bak pewarnaan, gunanya untuk tempat mewarnai kain. Bentuknya pada umumnya persegi panjang, bahannya dari kayu.

- Penjemuran, untuk menjemur kain pada saat menghilangkan kanji atau usai proses pembatikan.

Gawangan, gunanya untuk menyampirkan kain pada saat membatik atau dengan kata lain berfungsi menyerupai tempat jemuran. Gawangan dapat dibuat dari bambu atau kayu. Gawangan dibuat sedemikian rupa hingga mudah diangkat untuk dipindahtempatkan.

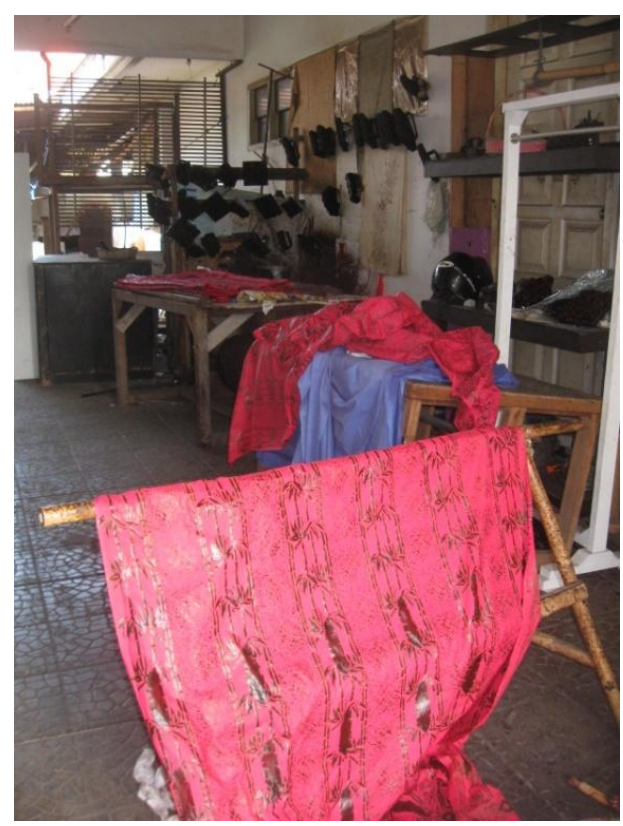

Gambar 6.Gawangan

Sumber: Ria Intani, 2016.

- Saringan, gunanya untuk menyaring kotoran yang terdapat di dalam malam/lilin panas. Kotoran yang tidak tersaring dapat menyebabkan tersumbatnya malam/lilin pada cucuk canting.

- Bangku, gunanya untuk tempat duduk pembatik pada saat membatik.

- Celemek, gunanya untuk menutup bagian paha pembatik agar tidak terkena tetesan malam/lilin. Baik pada saat malam/lilin ditiup oleh pembatik atau pada saat pembatik mengambil malam/lilin dari katel.

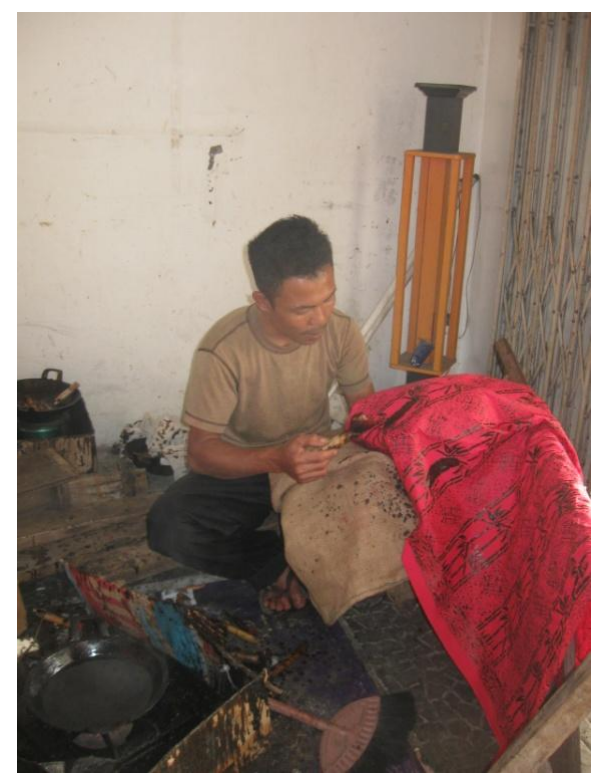

Gambar 7. Celemek di Atas Paha Pembatik Sumber: Ria Intani, 2016.

Secara garis besar, batik Cimahi dibuat denganmelalui proses sebagai berikut:

- Memotong kain,

- menghilangkan kanji agar warna batik menempel. Caranya dengan mencuci, merebus, dan menjemur kain. Namun demikian cara ini tidak berlaku untuk kain sutera dan semi sutera,

- memanaskan malam/lilin,

- membuat pola,

- pengecapan/penulisan,

- menutup malam,

- pewarnaan,

- membuang malam/lilin (nglorod),

- mencuci,

- menjemur,

- menyeterika. 


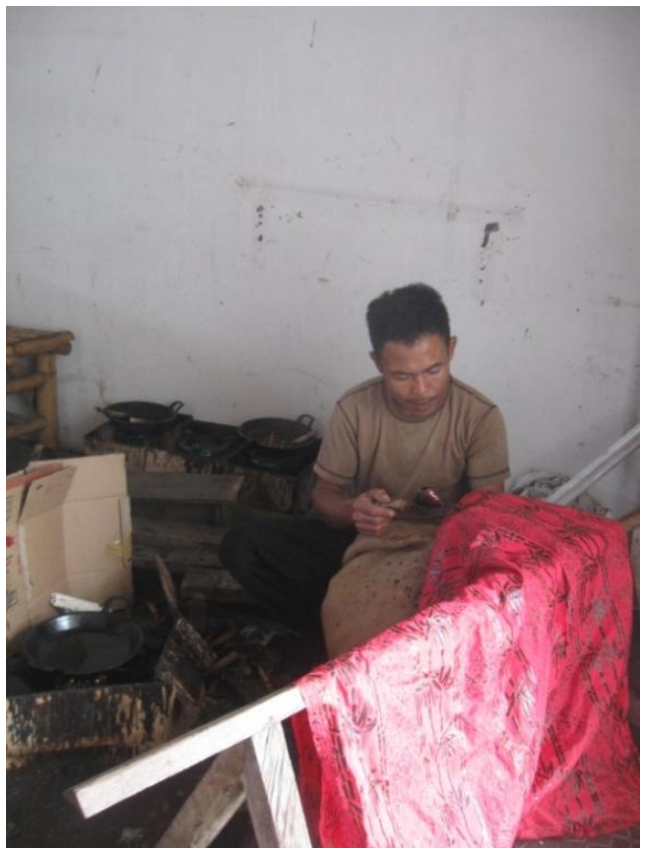

Gambar 8. Menyanting Sumber: Ria Intani, 2016.

Lembur Batik Cimahi memproduksi batik Cimahi lebih banyak didasarkan oleh pesanan. Meskipun hanya lima motif yang dibuat, namun demikian selanjutnya dari motif yang ada tersebut dikembangkan dengan cara dimodifikasi. Misalnya, motif ciawitali (motif dengan gambar bambu), penerapannya tidak melulu motif bergambarkan pohon-pohon bambu. Melainkan, dalam satu lembar kain terdapat gambar pohon bambu dengan satu jenis benda yang berbahan bambu, angklung misalnya. Contoh lain adalah motif curug Cimahi. Motif ini dikembangkan dengan cara menambahkan gambar pohon bambu di sekitar gambar curug. Adanya pengembangan dalam motifnya, selanjutnya motif batik produksi Lembur Batik Cimahi menjadi "berwarna".

Demi meluaskan konsumen, beberapa pameran pernah diikuti mulai dari tingkat lokal (kota), provinsi, hingga nasional. Selain di tempat pameran, konon pengunjung dan pembeli yang datang ke sanggar masih terbatas warga Cimahi dan sekitarnya.

\section{Perekrutan Pengrajin}

Lembur Batik Cimahi pada awal pendiriannya memiliki 13 orang pekerja. Mereka terdiri atas: 3 orang bekerja pada bagian pola dan cap, kesemuanya laki-laki; 5 orang bekerja pada bagian pola dan nyanting, kesemuanya perempuan; dan 3 orang bekerja pada bagian celup, kesemuanya laki-laki. Kesebelas orang tersebut berkutat di bengkel kerja. Adapun untuk pelayanan di toko, dipekerjakan 2 orang perempuan. Keseluruhan pegawai tersebut berasal dari Jalan Pesantren dan sekitarnya. Rata-rata pendidikan mereka lulusan dari sekolah menengah pertama (SMP) dan sekolah menengah atas (SMA). Tidak seorangpun dari mereka memiliki latar belakang pendidikan yang berbenang merah dengan pekerjaan sebagai pengrajin batik ataupun pelayanan di toko. Misalnya dari sekolah menengah kejuruan (SMK) yang berbidang seni rupa, tekstil, jurusan penjualan (PJ), atau akutansi.

Perekrutan calon pengrajin diawali dengan memberdayakan seorang pegawai yang membantu sang pengusaha batik di bidang usahanya yang lain, yang telah dirintis sebelumnya. Ia diminta oleh sang pengusaha batik untuk merekrut orang yang masih menganggur, yang tinggal di sekitar sanggar. Mereka direkrut untuk dilatih sebagai pengrajin batik. Ia juga yang nantinya bertugas memberikan pembelajaran membuat batik kepada calon pengrajin, seusai mengikuti kursus membatik. Didapatlah kemudian 13 orang seperti tersebut di atas.

\section{Pengetahuan Membatik}

Manakala sang pengusaha ingin membuka usaha batik, tidak seorang pun dari keluarganya yang memiliki kemampuan membatik. Olehkarenanya, sang pengusaha kemudian mengkursuskan membatik untuk pengrajin perintis. Kursus membatik berlangsung selama lebih kurang dua bulan, bertempat di salah satu sanggar batik ternama di Kota Bandung. Kursus dimulai dari nol, yakni berupa pengenalan jenis bahan, kain, dan 
peralatan yang digunakan, hingga proses pembuatan batik. Waktu kursus berlangsung selama enam hari, dari Senin hingga Sabtu, Minggu libur. Waktunya dari pukul 08.00-16.00 WIB. Dari dialah diharapkan ilmu atau pengetahuan tentang perbatikan itu diwariskan kepada caloncalon pengrajin.

Berikutnya, calon pengrajin diberikan pembelajaran membatik sesuai bagiannya masing-masing selama lebih kurang dua minggu.

\section{Kondisi Pengrajin}

Dari 11 orang calon pengrajin yang ikut dalam pembelajaran, tidak semuanya bertahan. Pada bagian nyanting, mengalami keluar masuk orang. Pada bagian nyanting, ada yang berhasil diberi pembelajaran dalam waktu 2 minggu, namun ada pula yang baru diberi pembelajaran selama seminggu, sudah keluar. Keluarnya mereka disebabkan sifat malas atau kurang tekun. Padahal, bagian nyanting adalah bagian yang paling memerlukan ketekunan dan kesabaran. Dua orang tersebut kemudian digantikan oleh orang baru. Demikian beberapa kali kondisi seperti ini terjadi.

Masalah yang berkenaan dengan pengrajin batik rupanya umum terjadi di mana-mana. Menurut Ariani (2013: 115), saat ini sulit mencari tenaga pembatik yang memiliki sifat sabar dan telaten. Kebanyakan yang masih bertahan adalah para pembatik yang telah berusia 50 tahun ke atas.

Tahun 2013, jumlah pengrajin mengalami pengurangan. Dari 11 pengrajin berkurang 4 orang, keseluruhannya dari bagian nyanting, hingga tersisa 7 pengrajin. Alasan keluarnya pengrajin bermacam-macam. Ada yang beralasan karena sudah berumah tangga dan kemudian hamil, dan alasan lain lebih karena faktor penghasilan sebagai pengrajin yang dirasakan tidak cukup memadai. Mereka yang memiliki alasan terkait besaran penghasilan, selanjutnya lebih memilih menjadi "pembantu lepas" di rumah-rumah. Tugas utama sebagai "pembantu lepas" adalah mencuci dan menyeterika pakaian. Adapun tugas lainnya adalah menyapu sekaligus mengepel lantai, dan mencuci piring. Jenis pekerjaan tersebut sesuai perjanjian di awal melamar kerja antara pihak pekerja dengan majikannya. Kesepakatan tersebut biasanya berkaitan dengan besaran upah yang akan diberikan majikan kepada pekerjanya. Oleh karena jenis pekerjaan yang harus ditangani sebagai "pembantu lepas" tidak banyak maka dalam satu keluarga (rumah tangga), mereka hanya bekerja sekitar 3 jam saja. Sedangkan sebagai pengrajin batik, mereka harus bekerja seharian, dari pukul 08.00-16.00 WIB. Dengan waktu yang dimiliki sebagai "pembantu lepas" sangat leluasa maka mereka bisa mendapatkan penghasilan yang lebih besar dibandingkan sebagai pengrajin batik. Mereka memanfaatkan waktu yang ada untuk bekerja pada 2 sampai 3 keluarga. Dengan demikian penghasilan per hari yang didapat bisa mencapai 2-3 kali lipat dari penghasilan yang didapat sebagai pengrajin batik dalam 1 hari.

Dengan keluarnya para penyanting, selanjutnya sang pengusaha batik tidak lagi merekrut warga sekitar yang memang masih nol kemampuan. Alasannya, khawatir apabila sudah diberikan pembelajaran sampai mampu membatik, mereka keluar. Berikutnya, pengrajin langsung diambil dari Cirebon yang sudah siap pakai. Mereka berjumlah lima orang.

Di tahun 2016, menjelang Hari Raya Idul Adha, pengrajin boleh dikatakan habis. Tujuh orang pada bagian pewarnaan dan cap beralih kerja. Alasannya, tidak lain karena besaran penghasilan yang dirasakan tidak cukup untuk memenuhi kebutuhan rumah tangga. Mereka yang beralih kerja, sebagian menjadi pengrajin batik pada sanggar batik yang baru berdiri dengan iming-iming gaji lebih besar, sedangkan sebagian lagi menjadi tukang bangunan dan lain-lain pekerjaan. Sementara 5 
pengrajin dari Cirebon untuk sementara pulang kampung terkait adanya rencana kepindahan lokasi sanggar. Demikian pula bagian pelayanan toko juga keluar namun kemudian sudah mendapatkan penggantinya. Tinggallah pengrajin seorang lagi, tak lain dan tak bukan adalah sang pengrajin perintis. Dengan kondisi demikian, apabila ada pesanan, semua tahapan dalam pembuatan batik menjadi dikerjakan sendiri. Tidak heran kalau kemudian waktu penyelesaiannya menjadi lebih lama.

Kondisi pengrajin seperti tersebut di atas, rupanya merupakan kendala yang umum dialami oleh sebuah usaha yang masih kecil. Seperti dipaparkan Haryadi dan kawan-kawan (dalam Taryati, 2013: 69) bahwa:

"kemampuan usaha kecil untuk tumbuh dan berkembang sangat dipengaruhi oleh kondisi eksternal dan internal. Faktor eksternal yaitu kebijakan, struktur pasar yang bekerja, akses informasi dan pelayanan serta jenis komoditas yang disediakan. Sedangkan faktor internal seperti strategi pemasaran, pola-pola produksi, pengelolaan ketenagakerjaan serta kewirausahaan."

Sumintarsih berpendapat sama bahwa kendala yang umum dialami oleh usaha industri rumah tangga adalah pemasaran, manajemen (dapat diartikan manajemen keuangan, tenaga kerja dan lain-lain), dan juga modal (Herawati, 2013: 10).

\section{Konsep Kerja}

Berikut adalah gambaran konsep kerja pengrajin yang masih bertahan di Lembur Batik Cimahi:

Enerji, bekerjanya sang perintis menjadi pengrajin batik oleh karena ia memiliki "kekuatan" yang mampu menahannya untuk tidak beranjak dari tempatnya bekerja. "Kekuatan" yang dimaksud, pertama adalah rasa tanggung jawab. Posisi dia menjadi perintis, ketiadaan sumber enerji di dalam keluarga, memunculkan rasa taggung jawab yang sangat besar. Ia menjadi sumber enerji. Ia satu-satunya orang yang menguasai hal ihwal pekerjaan membatik. Dia berpikiran, kalau tidak ada dia bagaimana atau siapa lagi yang akan mengurusi pekerjaan membatik di sanggar. Kedua, dari rasa tanggung jawab memunculkan rasa memiliki. Ketiga, ikatan emosional yang terjalin dengan sang pengusaha, setelah sekian lamanya bekerja dengan sang pengusaha. Dari bekerja sebagai tukang bangunan, tukang kayu, tukang mebel (sang pengusaha batik juga merupakan pengusaha mebel), dan pamungkas sebagai pengrajin batik. Keempat, dalam perkembangannya, bukan saja rasa tanggung jawab, rasa memiliki, dan ikatan emosional yang merupakan kekuatannya, melainkan rasa cinta dengan pekerjaan membatiknya yang kemudian muncul. Oleh karena itu, di tengah beragamnya jenis pekerjaan di masyarakat, adanya rasa cinta akan pekerjaannya, membuatnya ajeg sebagai pengrajin batik. Menurutnya, hanya pengrajin yang bekerja dengan hatilah yang mampu mengabaikan jenis pekerjaan yang lain. Keluarnya para pengrajin, tidak memengaruhi sang pengrajin perintis untuk tetap bertahan dengan pekerjaannya. Bahkan ia beranganangan, andaikan ia kelak memiliki cukup modal, ia ingin mendirikan sanggar sendiri.

Insentif, menurutnya, apabila berbicara pekerjaan sebagai pengrajin batik dilihat dari kaca mata besarnya penghasilan, relatif tidak cukup. Namun demikian menurutnya, kalaupun dia beralih pekerjaan dengan penghasilan yang lebih besar, pasti rasa kurang atau tidak cukup itu akan terus mengikuti. Sebabnya, manusia tidak akan pernah merasa puas dengan apa yang sudah didapatnya. Baginya, kalau pada awalnya bekerja semata-mata untuk mendapatkan penghasilan sebesar-besarnya, sekarang tidak lagi. Kepuasan batin juga menjadi target dalam bekerja. Kepuasan batin didapat manakala karya batik yang 
dibuatnya berkualitas, dapat memuaskan pemesan atau menawarkan daya tarik bagi pembeli. Selanjutnya dengan berbekal konsep kerja seperti itu, menjadi pengrajin batik tidak lalu asal-asalan. Sebagai pertanggungjawaban atas keputusannya menjadi pengrajin, pengrajin menjadi memiliki motivasi untuk dapat berkarya lebih baik dan lebih baik lagi.

Sumber, sebagai orang yang pada awalnya awam akan pembuatan batik, menjadi keharusan ia untuk belajar membatik. Tidak heran, ia mendapatkan ilmu membatik melalui kursus yang diikutinya selama dua bulan. Kursus atau pembelajaran diawali dengan mengenal bahan, jenis kain, ragam peralatan membatik, sampai dengan proses pembuatan batik. Pembelajaran lebih bersifat praktik, tidak teoritis. Dengan demikian pengrajin tidak belajar di bangku, melainkan di bengkel kerja. Sebenarnya menurut sang pengrajin, waktu dua bulan tergolong singkat untuk mempelajari semua materi. Hanya saja karena pada saat pembelajaran, ia relatif cepat menangkap dan mempraktikkan ilmu yang diberikan maka waktu dua bulan menjadi cukup. Dari semua materi yang diajarkan, praktik menyanting dirasakan paling sulit. Menyanting 'menorehkan/menuliskan malam/lilin dengan canting di atas kain', membutuhkan ketelitian, ketekunan, kesabaran, dan kelembutan dalam pengerjaannya agar hasilnya apik. Tidak heran untuk selembar kain batik tulis memerlukan waktu lebih dari satu bulan untuk menyelesaikannya hingga berdampak pada harganya yang "tinggi". Konon, pekerjaan menyanting lebih pas dilakukan oleh perempuan karena perempuan sifatnya lembut. Meskipun pengetahuan membatik sudah didapatkan di tempat kursusnya, ia menambahkan ilmunya dengan mencari dari berbagai sumber. Di antaranya, dari sesama pengrajin. Dalam hal ini pengrajin dari Cirebon yang didatangkan kemudian, yang dipandang memiliki kemampuan lebih karena jam terbang di dunia perbatikan yang sudah lebih lama.

Value, sang pengrajin perintis melihat bahwa rekan kerja adalah orang yang dihadirkan untuk saling melengkapi/ meringankan pekerjaan. Di dunia perbatikan, pekerjaan membatik terbagi pada beberapa bagian. Apabila salah seorang pekerja di suatu bagian tidak ada, akan menjadi pekerjaan tambahan alias beban bagi yang lain. Bahkan, apabila tidak ada pekerja yang mampu mengerjakan pekerjaan yang bukan menjadi tugasnya sehari-hari tersebut maka produksi tidak akan tuntas. Oleh karena itu antarrekan kerja di semua bagian harus saling menghargai.Tidak harus memandang yang satu lebih tinggi atau lebih rendah dari yang lainnya.

Waktu, baginya, waktu sangat berharga. Oleh karena itu selagi ada waktu, dia tidak mau ongkang-ongkang kaki alias bersantai ria. Ia akan mengerjakan apa saja. Maksudnya, apabila pekerjaan membatiknya belum lagi ada pekerjaan, ia akan kerja serabutan. Membersihkan halaman sanggar misalnya, atau apa pun yang bisa dikerjakan, apalagi baginya tempatnya bekerja sudah seperti rumah sendiri.

Tempat, Sanggar Lembur Batik Cimahi menempati suatu bangunan berarsitektur Belanda yang cukup luas. Baginya, tempat yang tersedia harus dimanfaatkan semaksimal mungkin. Dengan tempat yang sudah artistik dari bentuknya, satu nuansa dengan jenis barang yang diproduksi, diatur sedemikian rupa agar semua ruang termanfaatkan. Apabila tempat sudah tertata, hal yang tidak kalah pentingnya adalah masalah kebersihan yang harus selalu dijaga.

Orang (dorongan menjadi pekerja tertentu/kriteria memilih pekerja), membatik merupakan pekerjaan yang membutuhkan sifat: sabar, tekun, dan teliti. Pada umumnya orang paham akan hal itu. Namun demikian manakala sang pengrajin perintis diberi tugas oleh sang pengusaha batik untuk merekrut pekerja, bukan sifat 
seseorang yang menjadi pertimbangan utama. Melainkan, mereka yang tergolong usia kerja tapi belum memiliki pekerjaan, alias masih menganggur. Mereka yang masih menganggur dan mau terjun ke dunia perbatikan, itulah yang "ditangkap". Soal rasa suka dengan pekerjaan dan sifatsifat yang umum harus dimiliki pengrajin batik, menurutnya, akan terlihat pada saat diberikan pembelajaran nanti. Menurutnya, membatik memerlukan tingkat kesabaran, ketekunan, dan ketelitian yang tinggi. Oleh karena itu, hanya mereka yang memiliki rasa suka dengan pekerjaan membatik dan sifat-sifat seperti tersebut di atas yang akan dapat bertahan sebagai pengrajin batik.

Teknologi, peralatan serta cara yang digunakan untuk membatik di Sanggar Lembur Batik Cimahi, sama saja dengan peralatan dan cara membatik yang digunakan pada umumnya di dunia perbatikan. Pada prinsipnya, membatik merupakan pekerjaan yang sifatnya masih tradisional. Pengerjaannya secara manual, dan peralatan yang digunakan relatif sederhana dilihat dari kaca mata kekinian.

Sistem (pola keseluruhan dari langkah-langkah kerja), pekerjaan membatik dibagi bagian per bagian. Meskipun demikian, tidak berarti setiap orang akan memegang satu bagian pekerjaan. Ada satu orang yang merangkap lebih dari satu pekerjaan. Ada bagian yang mencuci kain untuk menghilangkan kanji. Orang yang memiliki tugas di bagian ini, ia merangkap mengerjakan pembuatan pola dan pengecapan misalnya. Bagian nyanting merangkap mengerjakan pembuatan pola. Pembagian pekerjaan tersebut sudah dipertimbangkan berat dan ringannya, serta ada benang merahnya atau tidak antara satu bagian dengan bagian yang lain. Adapun sistem penggajian ada dua versi. Ada yang dilakukan secara mingguan, ada pula secara bulanan. Sistem ini biasanya berdasarkan kesepakatan.

\section{PENUTUP}

Batik adalah kain yang menggunakan proses perintang malam atau lilin sebagai bahan media untuk membuatnya. Cara pembuatannya dapat dengan ditulis menggunakan canting, dicap dengan menggunakan cap, atau penggabungan antarkedua cara tersebut.Yakni, ditulis sekaligus dicap.

Penetapan UNESCO membuat batik menjadi booming. Sanggar batik bermunculan, model busana batik beragam, dan penggunaan batik menjadi tak berbatas ruang dan waktu. Fenomena tersebut memenuhi tiga unsur yang terdapat di dalam konsep pelestarian, yakni pengembangan dan pemanfaatan. Satu unsur lagi di dalam konsep pelestarian adalah perlindungan, yakni upaya pencegahan dari kepunahan. Hal yang sekiranya mampu menjaga batik dari kepunahan selain keberadaan konsumen, kunci awalnya tidak lain terletak pada keberadaan pengrajin.

Zaman yang sudah serba tek (baca: teknologi), yang mana jenis pekerjaan sudah sangat beragam, menyurutkan orang untuk menggeluti dunia perbatikan. Dunia yang memerlukan ketekunan, ketelitian, dan kesabaran, juga rasa cinta.

Tidak seperti tempat perbatikan pada umumnya yang mana sumber energi (tenaga ahli) ada di dalam lingkungan keluarga dan kemudian meluas pada masyarakat di sekitarnya. Di Lembur Batik Cimahi, energi (pekerja) "diciptakan", dengan mengambil orang untuk dikursuskan dan menyebarkan pada beberapa orang untuk selanjutnya menjadikannya sebagai pengrajin batik. Namun demikian manakala materi menjadi pertimbangan nomor satu, tidak ada rasa memiliki, tidak ada rasa cinta (bekerja tanpa hati), dan tidak memiliki sifat yang dibutuhkan dalam dunia perbatikan, habislah pengrajin itu. Kiranya, konsep kerja pengrajinlah yang mampu mempertahankan pengrajin batik untuk tidak lari pada jenis pekerjaan yang lain. Kerja memang untuk mencari nafkah. 
Namun demikian di mata pengrajin yang setia pada pekerjaannya, kerja tidak melulu mengutamakan materi, melainkan juga harus dapat memberikan kepuasan batiniah.

Partisipasi warga masyarakat dalam rangka menguatkan pengakuan dari UNESCO dengan mendirikan sanggar, perlu didukung dan diapresiasi oleh pemerintah. Sehubungan dengan itu, terkait tidak banyaknya pengrajin batik di luar daerah perbatikan, seperti halnya Kota Cimahi, ada baiknya instansi terkait mengadakan pelatihan secara cuma-cuma kepada warganya untuk menyiapkan tenaga kerja pembatik di daerahnya.

Dunia perbatikan yang kalah saing dengan "batik" pabrikan, membuat seringkali produksi tersendat-sendat. Kondisi seperti itu merupakan salah satu penyebab pada besarnya penghasilan pengrajin yang tidak dapat maksimal. Atas kondisi tersebut, pemerintah setempat berkewajiban menciptakan strategi, salah satunya dengan menggiring lebih banyak lagi warganya untuk mengenakan batik Cimahi. Misalnya, dengan membuat kebijakan di mana pada hari-hari tertentu, setiap karyawan bukan saja di lingkungan pemerintah, namun juga swasta, dan sekolah yang berada di wilayah administrasi Kota Cimahi, wajib mengenakan busana batik Cimahi. Dengan demikian batik Cimahi akan terus menggeliat dan berujung pada semangat pengrajinnya.

\section{UCAPAN TERIMA KASIH}

Terima kasih diucapkan kepada Bapak Triwanto selaku pemilik Lembur Batik Cimahi serta Bapak Somantri selaku pengrajin batik yang telah menyediakan waktu untuk diwawancara.

\section{DAFTAR SUMBER}

\section{Jurnal, Skripsi, Makalah}

Hayati, Chusnul. "Batik Pekalongan: Besar karena Benturan" dalam Patrawidya Vol. 13 No. 1.Maret 2012.Hlm. 25-26.
Intani, Ria. "Regenerasi Topeng Randegan" dalam Patanjala Vol. 8 No. 3. September 2016. Hlm. 22.

Kartawinata, Ade M. "Persepsi tentang Etos Kerja Kaitannya dengan Nilai Budaya Masyarakat", Makalah, Bandung, 25 Juni 1994

Lasmiyati. 2012. "Batik Cimahi”, dalam Bunga Rampai Pelestarian Budaya dan Sejarah Lokal.

Purwaningsih, Ernawati. "Pewarisan Tradisi Membatik di Desa Kotah, Sampang, Madura" dalam Patrawidya Vol. 16 No. 4.Desember 2015.Hlm. 466.

Sarmini."Pakaian Batik: Kulturisasi Negara dan Politik Identitas" dalam Jantra Vol. IV No. 8.Desember 2009. Hlm. 674-675.

\section{Buku}

Abdullah, Taufik. 1978.

Agama Etos Kerja dan Perkembangan Ekonomi. Jakarta: LP3ES.

Ariani, Christriyati. 2013.

Batik Gentongan Tanjungbumi Bangkalan Madura dalam Kerajinan Batik dan Tenun (Lono Lastoro Simatupang, Pengantar). BPNB Yogyakarta.

Garna, Yudistira K. 2009.

Metoda Penelitian Kualitatif. Bandung: The Judistira Foundation dan Primaco Akademika.

Hamzuri. 1994.

Batik Klasik. Jakarta: Djambatan.

Herawati, Isni. 2013.

Kerajinan Kuningan di Bejijong Mojokerto: Bahan Baku, Teknologi Produksi dan Pemasaran dalam Kerajinan Tradisional (Andri Kurniawan, Pengantar). BPNB Yogyakarta.

Taryati. 2013.

$\begin{array}{lcc}\text { Kerajinan } & \text { Ukir Kayu di } & \text { Desa } \\ \text { Kanduluk } & \text { Sumenep Madura dalam } \\ \text { Kerajinan } & \text { Tradisional } & \text { (Andri } \\ \text { Kurniawan, } & \text { Pengantar).BPNB } \\ \text { Yogyakarta. } & & \end{array}$


Tim Redaksi KBBI. 1988.

KamusBesar Bahasa Indonesia.

Jakarta: Gramedia.

Tim Redaksi KBBI. 2013.

KamusBesar Bahasa Indonesia Edisi

Keempat. Jakarta: Gramedia.

Wallman, Sandra. 1979.

Social Anthropology of Work.

London, New York Toronto Sydney

San Francisco: Academic Press.

\section{Internet}

http://www.cimahikota.com/data-wilayah-kotacimahi.html, diakses tanggal 23

Desember 2016, pukul 19.10 WIB. 